\title{
RECENT TRENDS IN GLOBAL FDI FLOWS: IMPLICATIONS FOR THE $21^{\mathrm{ST}}$ CENTURY
}

\author{
CHIAKU CHUKWUOGOR NDU \\ Eastern Connecticut State University
}

\begin{abstract}
This paper examines recent global trends of foreign direct investment, (FDI) flows and the benefits derivable by the recipient countries. Some of The developed countries of the West, Japan and China are the greatest recipients of FDI flows. There has been dramatic increase in FDI flows to developing countries in Asia, Latin America and the transition countries in Europe. In general developing countries are still unable to attract significant FDI. Africa's share of the FDI flows though slightly on the increase has been abysmally low. The identifiable reasons for this trend were highlighted. To achieve a more balance flow of FDI in the $21^{\text {st }}$ century, a concerted effort should be made by international organizations, leading world government, multinational enterprises and governments of developing economies, through dialogue and negotiations to encourage multinational enterprises to diversify their investments across developing economies otherwise marginalized by globalization and liberalization.
\end{abstract}

\section{Introduction}

According to the United Nations (1997), foreign direct investment accounted for 25 percent of total international capital flows. The average yearly outflow of FDI increased from $\$ 25$ billion in 1975 to $\$ 430$ billion in 1998 . 1t accelerated faster than other forms of international investment and the growth in world trade. Foreign direct investment occurs when a firm invests directly in facilities to produce products in a foreign country or to market such products. According to the U.S. Department of Commerce, FDI occurs whenever a U.S. citizen, organization, or affiliated group takes an interest of 10 percent or more in a foreign business entity. Therefore, most international foreign direct investors are, by nature, multinational enterprises. When a firm decides to engage in FDI rather than in the traditional export procedure, it is pursuing the wealth maximization objective. For purposes of clarity, we mean that a firm is attempting to create more value for its shareholders than is 
available in its domestic market. The benefits to be derived by host countries are not a major consideration of the firms engaging in FDI except if these are requirements in any pre-investment dialogue or negotiation with host government. Conditions such as trade barriers, access to markets, cost considerations, political considerations and other yet unexplained variables make FDI investments in certain locations of the world more attractive than in others.

\section{Objective}

This paper provides an overview of global flow of FDI in order to determine particular trends, the determinants of such trends, expected benefits of recipient countries and the negative effects on FDI deprived countries or continents. It further explores the policy implications for a more balanced flow of global FDI.

\section{An Overview of Foreign Direct Investment}

Between 1984 and 1998, the total flow of FDI from all countries increased by 900 percent to over $\$ 4.0$ trillion, while world trade grew by 121 percent, and world output by 34 percent (WTO,1998, United Nations, 1998). Partially responsible for the recent increases in the volume of Foreign Direct Investment are the general shifts toward democratic political institutions, free market economies, economic growth and deregulation. Also, privatization programs open to foreign investors and removal of many restrictions on FDI, and liberalization of various countries foreign investment regulations to make it easier for foreign companies to enter their market have also given impetus to greater flow of international direct investment. For example, between 1991 and 1996 over 100 countries made 599 changes in legislation governing FDI (United Nations,1998).

\section{Merits/Demerits of FDI to National Economies}

Foreign direct investment has served many purposes to world economies. The flow of foreign direct investment into a country increases the level of domestic investment in that country in excess of the country's level of savings. The achieved increase in capital investment precipitates economic growth in that country without significant decrease in current consumption. There is a simultaneous increase in employment, general increase in income levels and possible transfer of technological know-how. These in turn generate entrepreneurial activities in the host country, especially in developing coun- 
tries. There is a lot of recent literature in support of this. FDI enhances technological change through technological diffusion, because multinational enterprises (MNEs) are concentrated in industries with a high ratio of Research and Development relative to sales and a large share of technical and professional workers (Marcusen, 1995). FDI not only contributes to imports of more efficient foreign technologies but also generates technological spillovers for local firms. "The knowledge spillovers may take place via imitation, competition, linkages and /or training" (Kinishita, 1998: Sjoholm, 1999). It also smoothens the impact of economic fluctuations resulting from seasonal fluctuations, shortage of supplies or price disequilibrium and other economic dislocations of a temporary nature. At the same time, it permits consumption and capital formation to be at least partially sheltered (Sing \& Kwang 1995). Empirical evidence suggest that FDI's generation of positive spillovers for local firms is mixed (Saggi, 2000) Some studies find positive spillover effects, some find no effects and some even conclude that they are negative effects (Aitken and Harrison, 1999). A comprehensive study by Bosworth and Collins (1999) provides evidence on the effect of capital inflows on domestic investment for 58 developing countries during 1978-95. The sample covers nearly all of Latin America and Asia, as well as many countries in Africa. The authors distinguish among three types of inflows: FDI, portfolio investment, and other financial flows (primarily bank loans). Bosworth and Collins find that an increase of a U.S. dollar in capital inflows is associated with an increase in domestic investment of about 50 cents. (Both capital inflows and domestic investment are expressed as percentages of GDP.) This result, however, masks significant differences among types of inflow. FDI appears to bring about a one-for-one increase in domestic investment. Borensztein, De Gregorio, and Lee (1998) find that FDI increases economic growth when the level of education in the host country - a measure of its absorptive capacity - is high.

One explanation for this paradox is that FDI is more likely than other forms of capital flows to take place in countries with missing or inefficient markets. In such settings, foreign investors will prefer to operate directly instead of relying on local financial markets, suppliers, or legal arrangement (Loungani and Razin, 2001). The policy implications of this view, according to Albuquerque (2000), are "that countries trying to expand their access to international capital markets should concentrate on developing credible enforcement mechanisms instead of trying to get more FDI."

In a similar vein, Hausmann and Fernández-Arias, (2000) suggest that "Countries should concentrate on improving the environment for investment and the functioning of markets. They are likely to be rewarded with increasingly efficient overall investment as well as with more capital inflows." 
Although it is very likely that FDI is higher, as a share of capital inflows, where domestic policies and institutions are weak, this cannot be regarded as a criticism of FDI per se. Indeed, without it, the host countries could well be much poorer. FDI is not only a transfer of ownership from domestic to foreign residents but also a mechanism that makes it possible for foreign investors to exercise management and control over host country firms-that is, it is a corporate governance mechanism. The transfer of control may not always benefit the host country because of the circumstances under which it occurs, problems of adverse selection, or excessive leverage.

Through FDI, foreign investors gain crucial inside information about the productivity of the firms under their control. This gives them an informational advantage over "uninformed" domestic savers, whose buying of shares in domestic firms does not entail control. Taking advantage of this superior information, foreign direct investors will tend to retain high-productivity firms under their ownership and control and sell low-productivity firms to the uninformed savers. As with other adverse-selection problems of this kind, this process may lead to over investment by foreign direct investors (Loungani and Razin, 2001).

Excessive leverage can also limit the benefits of FDI. Typically, the domestic investment undertaken by FDI establishments is heavily leveraged owing to borrowing in the domestic credit market. As a result, the fraction of domestic investment actually financed by foreign savings through FDI flows may not be as large as it seems because foreign investors can repatriate funds borrowed in the domestic market.

There are some other cases in which FDI might not be beneficial to the recipient country - for instance, when such investment is geared toward serving domestic markets protected by high tariff or non-tariff barriers. Under these circumstances, FDI may strengthen lobbying efforts to perpetuate the existing misallocation of resources. There could also be a loss of domestic competition arising from foreign acquisitions leading to a consolidation of domestic producers, through either takeovers or corporate failures (Loungani and Razin, 2001).

Recently research findings indicate that the volatility of FDI is quite high in developing countries. The average value for 88 countries over almost 30 years, implies that FDI vary by 50 percent from year to year. Volatility to FDI shows consistently negative relationship to economic growth (Lensik and Morrissey, 2001). This observation does not imply that FDI volatility is a cause of poor. Rather it reiterate earlier findings that the factors that cause poor growth performance may discourage FDI flows

FDI opportunities enable foreign investors to take advantage of higher returns on investment available outside their home economy. Innovation based 
multinational companies such as N.V Philips (Netherlands), Sony (Japan) continue to dominate the market by continually introducing new products and differentiating existing ones. Others like Coca-Cola, Macdonald's, Nestle, and Proctor and Gamble take advantage of enormous advertising expenditures and highly developed marketing skills to differentiate their products and exploit the premium associated with their strong brand names. The location of natural resources in great abundance compel some multinational companies such as Shell, Texaco and Philips to locate in such countries because of the extractive nature of the industry (Shapiro, 1999). Besides, recently the need to achieve size for greater international competitiveness has led to various transnational mergers especially in the automobile, pharmaceutical and the financial services industries (Wayne, 1998). Increased global dispersion of production facilities provide MNEs a more flexible response to global changes in interest and exchange rates. Advances in technology and telecommunications has helped to increase the flexibility of production and reduced the adjustment costs associated with the shifting of the global location of production (Kregell, 1996).

\section{Recent Trends in FDI Flows}

An assessment of the flow of FDI since 1990 indicate that the United States was consistently the dominant provider of FDI between 1991 and 1997. See Chart 1 below.

\section{Chart 1}

\section{Trend of U. S. direct investment 1990-1997}

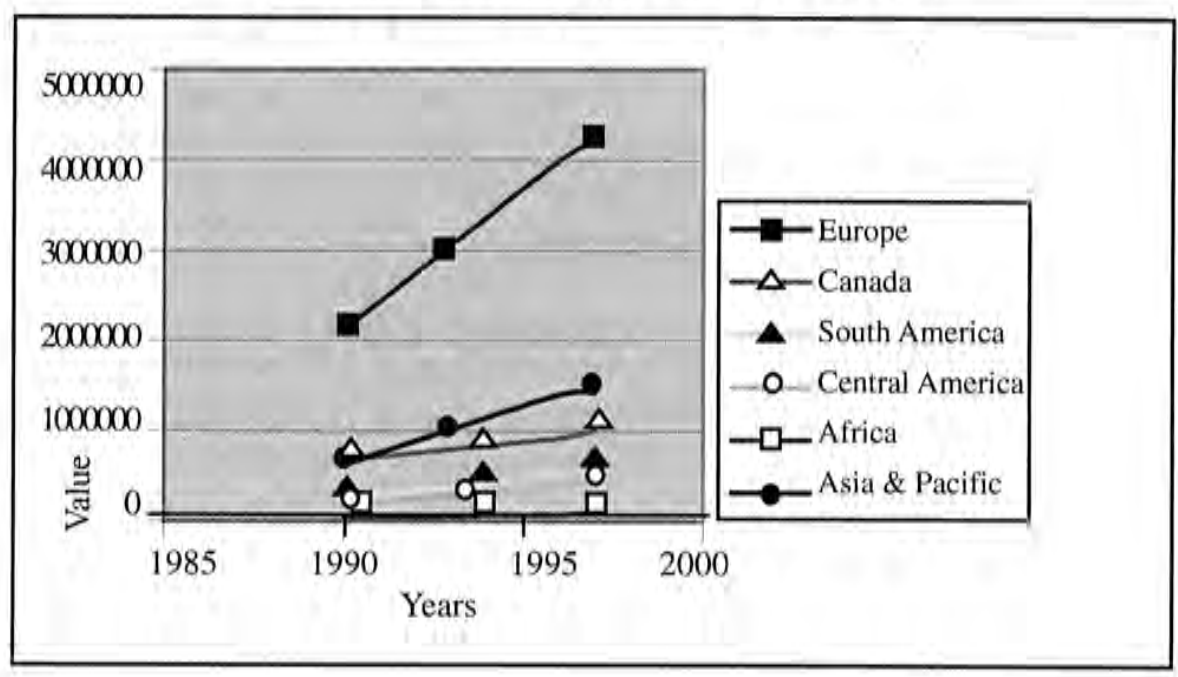


In 1991, FDI accounted for just under $\$ 40$ billion and it increased to over $\$ 114.5$ billion in 1997. The Direct Investment flows for OECD countries indicate that the U.S. FDI out flows was estimated at $\$ 123.5$ billion for 1998 (Simon \& Schuster, 2000). The foreign direct investment flows of OECD countries for the period 1996 to 1998 is contained in Table 1 in the appendix. The U.S dominance in the provision of FDI is not surprising. By 1980, 178 of the world's largest 382 MNEs were U.S. firms (Simon \& Schuster. 1987). The end of the cold war ushered in a new era of political stability and expanding capitalism, opening new markets in Europe and Asia.

Further, as a result of U.S. booming economy and surging U.S. Stock market in the last decade, U.S. companies consolidated themselves into bigger corporate giants through mergers and acquisitions. For example, in 1997 alone, $\$ 1$ trillion in mergers took place involving U.S companies. Practically every industry in the U.S was affected: from telecommunications to banking and from aerospace to accounting. With the advantages of a strong dollar, great corporate resources, political stability, economic boom and a culture deep in the knowledge and practice of capitalism, the U.S multinationals have dominated globally in international mergers, acquisitions and other direct investment activities. For example, in the recent merger and acquisition activity in the UK Electricity, U.S. utilities have acquired eight of twelve privatized regional electricity companies. The value of these acquisitions exceeded $\$ 25$ billion (Wayne, 1998). Table 2 in the appendix shows Recent Merger and Acquisition in UK Electricity. Table 3 in the appendix shows U.S. Direct Investment abroad in selected countries and countries and territories between 1990 and 1997.

The United Kingdom's share of FDI out flows increased from under $\$ 20$ billion in 1991 to over $\$ 63.7$ billion in 1997 . The other major contributors to the out flow of FDI were Germany, France and Japan and some developing countries in Asia. By 1997, Germany was contributing approximately $\$ 40.3$ billion, France $\$ 35.6$ billion, Japan $\$ 26$ billion and developing countries over $\$ 55$ billion. The FDI outflows from developing countries increased from an annual average of $\$ 10.5$ billion between 1985 and 1990 to $\$ 55$ billion in 1997, (Hill, 2000). The bulk of FDI out flows from developing countries came from such countries as Hong Kong, Singapore and South Korea. The impact of the 1997 financial crisis in Southeast Asia on this observed growth of FDI outflows from developing countries is yet to be known (Hill, 2000). Interestingly, from 1991-1997 approximately two thirds of FDI inflows annually went to developed countries and about one third went to developing countries in Asia and Latin America.

The major providers of FDI were also in general, the major recipients (United Nations, 1998). For example, in 1997, U.S. received $\$ 90.71$ 
billion, the U.K $\$ 37.05$ billion, France $\$ 23.12$ billion, Belgium/ Luxembourg $\$ 12.45$ billion, Sweden $\$ 10.90$ billion and Germany $\$ 9.6$ billion. Trans Atlantic mergers of MNEs have been cited as the main reasons for the recent jump in FDI to Europe and the U.S. The second reason for the inflows of FDI to Europe is the vast opportunity created by the European Economic Community. The prospective gains from the European by the year 2002, is related. Others are stable economic environments, increased privatization and liberalization of regulations to favor FDI. For the U.S, its attraction for FDI inflows is based on it dynamic, wealthy and economy, a favorable political climate and openness to FDI. Countries like United Kingdom, Japan, Germany, Holland and France find these factors particularly attractive. The increase in FDI flows to developing economies in the late 1980s encouraged intensified competition between developed and developing economies to attract FDI (Loots, 2000) For example, developing economies' share in world FDI flows upped from 21 percent in 1998 to about 42 percent in 1997 (UNCTAD, 1998).

Even though the Asian financial crisis curtailed FDI flows to developing economies in 1998, FDI flows to these economies increased significantly from $\$ 26.7$ billion in 1990 to about $\$ 183$ billion in 1998 (IFC, 1997 , UNCTAD, 1999). Table 3 in the appendix contains Net Long-term flows to developing countries for the period 1990-1999 and Chart 2 below illustrates the FDI flows to developing countries between 1990-1999.

Chart 2

Net FDI fows to developing countries 1990-1999 (billions of U.S. dollars)

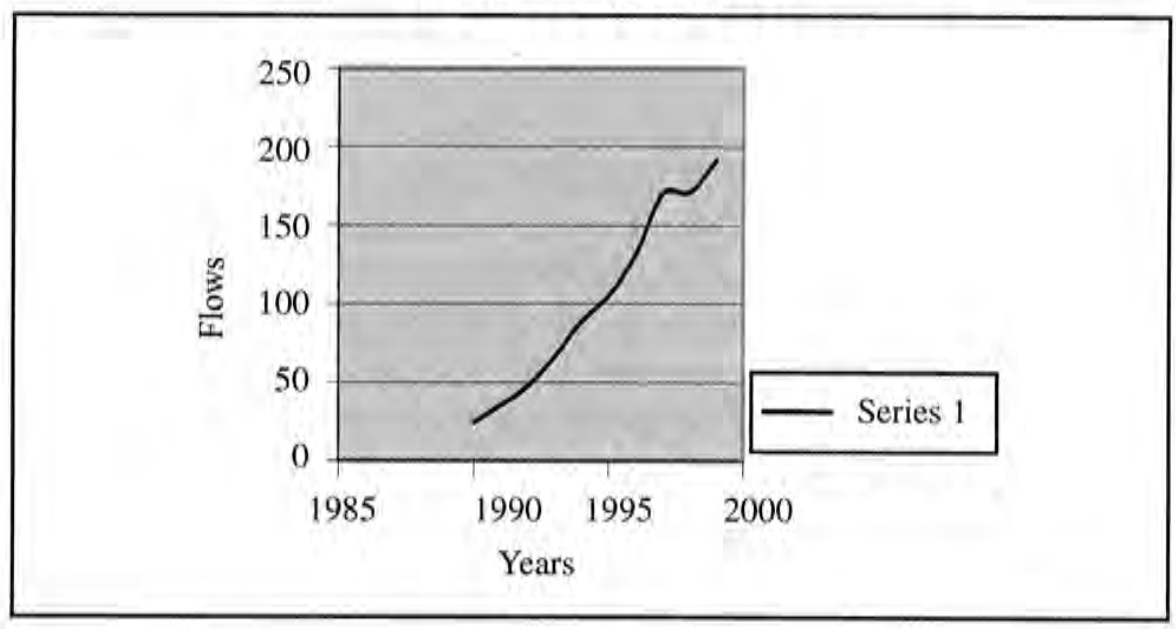

Source: Derived from World Bank Debtor Reporting system's statistics 
It has grown faster than other forms of international flows, second only to private flows. See Chart 3 below.

\section{Chart3}

Net long-term flows to developing Countries 1990-1999

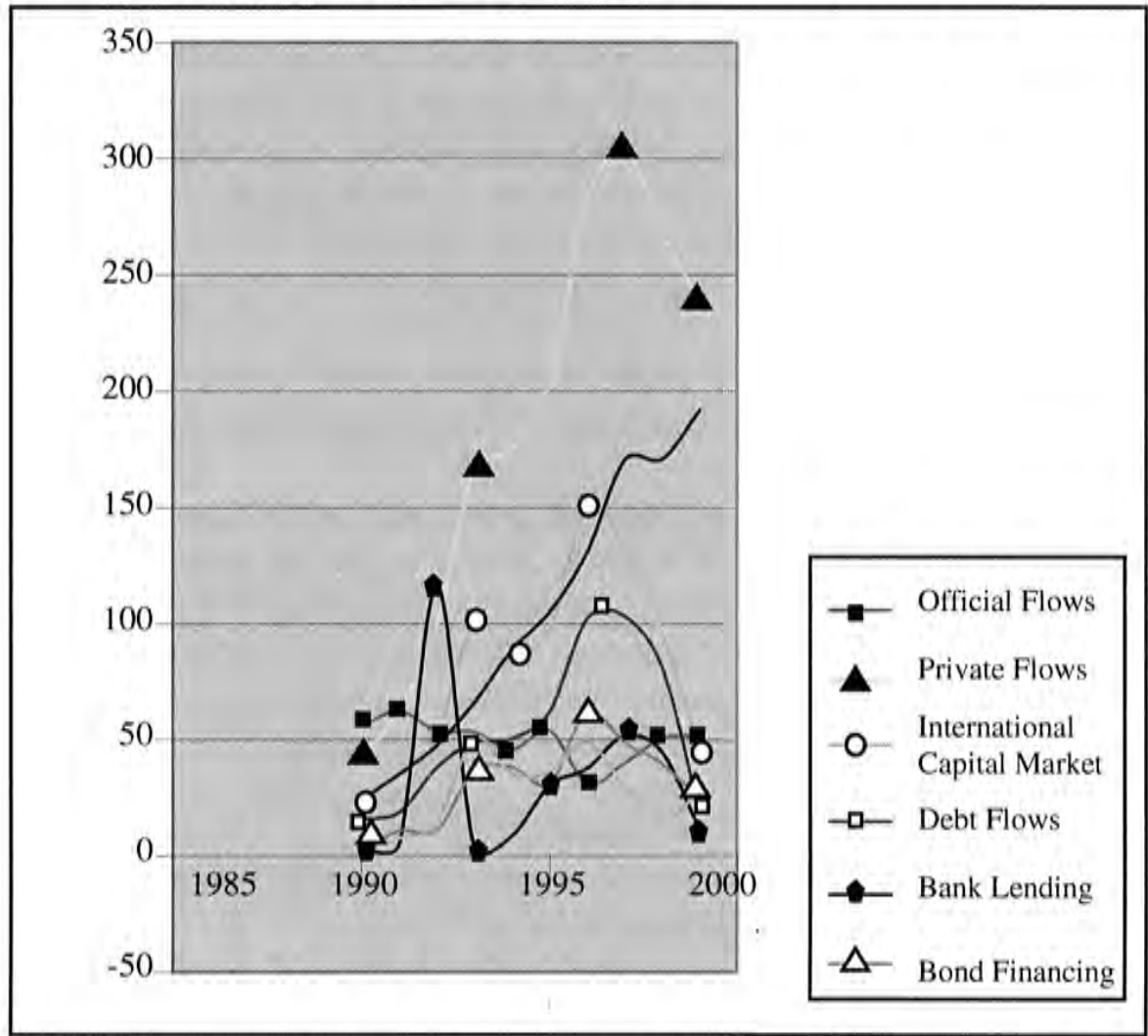

The major developing economy recipients were China, Brazil, Mexico and Singapore who received $\$ 45$ billion, $\$ 16$ billion, $\$ 12$ billion and $\$ 9$ billion respectively.

For China, its attractiveness to FDI include its moderate switch from a centrally planned system to a more market driven one; the quadrupling of GDP since 1978; the largest potential market in the world by virtue of its population of 1.2 billion people, the difficulty of serving the Chinese market through exports because of import tariffs; and a combination of cheap labor and tax incentives. All these make China an attractive location for establishing productive facilities to serve the Asian and world market with exports. Despite these advantages, China still has similar problems to other developing economies. With a per capita income of approximately $\$ 700$, it lacks the 
purchasing power for many Western consumer goods. Other problems include lack of a well-developed transportation infrastructure or distribution system, constantly shifting regulatory system, lack of qualified personnel, inexperienced opportunistic local joint venture partners with different corporate goals. To counter these problems, China committed $\$ 800$ billion in infrastructure projects. She pursues a macroeconomic policy of steady economic growth, low inflation, and a stable currency. The Chinese government in 1997 instructed Universities to establish 30 business schools to train Chinese people in basic skills such as accounting, finance, and human resource management (Hill, 1999)

While most of the developing world is experiencing a boom in terms of FDI flows, the continent of Africa has failed abysmally in attracting FDI in recent years. Although Africa was the second largest recipient of FDI flows in the early 1970s, their share has eroded ever since. For example, from 1993 to 1998 , African region's share of FDI was 4.7 percent of the total FDI flows to developing regions, in comparison to 33 percent to Latin America and Caribbean and 53 percent for Asia and the Pacific (IFC, 1997, UNCTAD, 1999). Despite the fact that most African nations made significant political and economic progress in recent years, Africa has faced near exclusion in the share of FDI flows. For example, the whole continent of Africa received only $\$ 5$ billion in 1997(Hill, 1999). This was so, even though most of Africa has made significant economic progress in recent years. Real gross domestic product (GDP) averaged nearly 4 percent in the past five years, with some countries reaching 5 to 8 percent. Per capita income is on the rise and average annual inflation is in single digit (Camdessus, 2000).

\section{Determinants of Foreign Direct Investment Flow}

Many scholars have tried to quantitatively analyze the factors that determine the flow of foreign direct investment and the general conclusion seems to be that export orientation is the strongest variable explaining why a country attracts foreign direct investment. Other factors are political risk, business conditions and macroeconomic variables (Singh and Jun, 1995). The observations we have made here show that in addition to the above, the size of the current or potential market as viewed by investors to a great extent determines the flow and magnitude of foreign direct investment. This is irrespective of whether the size of the market to be served is determined on a country or regional basis. The intensified flow of FDI to China in spite of its still relatively regulated economy and its developing economic characteristics are proof of this. The United States has all the variables required for FDI flows 
including a large and wealthy market and membership of North American Free Trade Agreement, (NAFTA). Even though the U.K. has opted out of the European monetary Union, it continues to attract huge FDI inflows because of similar reasons as the U.S. and in addition it gives foreign investors access to the huge European market. FDI inflows increased to countries such as Ireland and Spain since they joined the EU and to Mexico since its membership NAFTA.

\subsection{Policy Implications of Recent Global FDI Flows}

The benefits of FDI far out weigh the disadvantages. The benefits such as increase in domestic investments, economic growth, employment, income levels, entrepreneurial activities and possible transfer of technological know-how (to name but a few) are fundamental to economic development especially in developing economies. Yet despite the observed increased of FDI in general to developing countries, most developing countries still suffer deprivation of FDI and experience volatility in the flows. In the present state of globalization and liberalization, most developing countries that are susceptible and vulnerable to economic shocks will continue to lack FDI unless there is a global concerted effort to encourage a more equitable distribution of FDI. Granted that MNEs most pursue profitability in their international investments, they can be encouraged to maintain stability in FDI even when countries are facing temporary economic disequilibria for purposes of international economic stability and reduction of world poverty. The MNEs can be further encouraged to invest in other politically stable and relatively economically stable developing countries that do not have the profile of China. Very often the focus on policy actions to attract FDI is on host countries.

In addressing strategies for sustained economic development in order to attract FDI in Africa, Chukwuogor-Ndu and Enyinda, (2001), proposed the following policy objectives for African countries:

- Maintenance of political stability devoid of internal or external conflict,

- Eradication of poverty

- Stimulation of private and public sector for increased productivity that should lead to sustained high growth in GDP,

- Control of population explosion

- Provision of good quality education that emphasizes general technological skill development and the spirit of entrepreneurship 
- Ensuring of effectiveness of regional integration activities already in place

- Improving the physical infrastructure to facilitate transportation and communication

- Increase in domestic savings and investment

- Reliance on internal financing where possible and borrow at reasonable terms to finance crucial facilities that enhance economic development.

Pursuing the above objectives should make most developing countries attractive for FDI especially with the low cost of materials, labor and facilities. This paper observed that even though many African countries have maintained political stability, achieved high GDP growth rates and general advancement in the above objectives, most of the African countries still experience paucity in FDI flows. Even though there has been increased flow of FDI to developing countries in Asia and Latin America, such flows are not evenly distributed. The FDI flows to many developing countries in Asia and Latin America are still deficient. In addition to the host governments efforts to attract FDI, there should be deliberate and concerted effort and dialogue by international organizations (such as World Bank), multinational Corporations, leading world nations (Such as the U.S.) and governments of developing countries towards achieving a more balanced flow of FDI.

\section{Conclusion}

In the absence of a concerted effort to ensure a more balance flow of global FDI, a great portion of FDI will continue to go to Europe, North America and China in the $21^{\text {st }}$ century. The European Community is likely to expand to incorporate more European countries. The huge market in China is not likely to reach saturation in the $21^{\text {H }}$ century. For many countries, especially developing countries, that do not have the size of China, it is not just enough to be export oriented, politically stable, have a high GDP growth rate and maintain acceptable business conditions. To be more competitive in attracting FDI, countries within a particular geographical area should establish huge markets for free flow of goods and services. Regional economic integration is key to attracting FDI in the $21^{1 \mathrm{st}}$ century. 
Recent Trends In Global FDI Flows: Implications For The 21st Century

\section{APPENDIX \\ Table 1}

Foreign direct investment flows (FDI), OECD countries, 1996-1998 (\$ U.S. million)

Inflows

Out flows

\begin{tabular}{|l|r|r|r|r|r|r|}
\hline Country & 1996 & 1997 & $1998 \mathrm{p}$ & 1996 & 1997 & $1998 \mathrm{p}$ \\
\hline Australia & 5106 & 8724 & 6494 & 5921 & 5913 & 671 \\
\hline Austria & 4429 & 2385 & 5914 & 1935 & 1948 & 3013 \\
\hline Belgium - Luxembourg & 14061 & 12451 & 20887 & 8065 & 7742 & 23111 \\
\hline Canada & 6820 & 7131 & 15466 & 11615 & 14026 & 26807 \\
\hline Czech Republic & 1429 & 1301 & 2540 & 153 & 25 & 55 \\
\hline Denmark & 776 & 2801 & 6452 & 2518 & 4210 & 3868 \\
\hline Finland & 1109 & 2113 & 11121 & 3596 & 5284 & 19821 \\
\hline France & 21960 & 23178 & 28864 & 30419 & 35591 & 39773 \\
\hline Germany & 5637 & 9605 & 19888 & 50829 & 40285 & 86641 \\
\hline Greece & 5888 & 3586 & 3709 & & & \\
\hline Hungary & 1983 & 2085 & 1935 & -3 & 431 & 481 \\
\hline Iceland & 82 & 149 & 112 & 62 & 51 & 99 \\
\hline Ireland & 1888 & 1676 & 2236 & & & \\
\hline Italy & 3535 & 3698 & 1212 & 6465 & 10619 & 15591 \\
\hline Japan & 228 & 3224 & 3193 & 23424 & 25991 & 24153 \\
\hline Korea & 2325 & 2844 & 5143 & 4670 & 4449 & 4756 \\
\hline Mexico & 9185 & 12478 & 10238 & & & \\
\hline Netherlands & 14754 & 9198 & 22491 & 31646 & 19955 & 35942 \\
\hline New Zealand & 3697 & 1832 & 1930 & -1260 & -1605 & 343 \\
\hline Norway & 3257 & 3630 & 3600 & 5901 & 5016 & 2546 \\
\hline Poland & 4498 & 4908 & 5129 & 53 & 45 & 163 \\
\hline Portugal & 1315 & 2520 & 1773 & 749 & 1918 & 2923 \\
\hline Spain & 6468 & 5540 & 8680 & 5222 & 10142 & 15427 \\
\hline Sweden & 3078 & 10905 & 18900 & 4664 & 12641 & 21231 \\
\hline Switzerland & 722 & 805 & 940 & 110 & 251 & 367 \\
\hline Turkey & 76453 & 90748 & 192878 & 74883 & 114537 & 123467 \\
\hline United Kingdom & 231843 & 271510 & 465268 & 321865 & 399955 & 566206 \\
\hline United States & & & & & \\
\hline TOTAL OECD & 37051 & 63545 & 34125 & 63734 & 114957 \\
\hline
\end{tabular}


Recent Trends In Global FDD Flows: Implications For The 21st Century

p: provisional

1. The series shown is new due to a change in the methodology

2. The above amounts include entrepreneurial capital net and real estate investment.

3. The results shown are net (inward and outward) direct investment capital flows.

4. Data are based on fiscal year ending 31 March.

5. Data for 1996 and 1997 are also provisional.

As from 1996, the totals include estimates of reinvested earnings.

Source: OECD, International Direct Investment Dtabase

Table 2

Recent merger and acquisitions in UK electricity (million dollars)

\begin{tabular}{|c|c|c|c|}
\hline Regional Electricity Companies & Acquirer/Merger Partner & $\begin{array}{c}\text { Year of } \\
\text { Acquisition }\end{array}$ & $\begin{array}{l}\text { Value in } \\
\text { \$Billion }\end{array}$ \\
\hline \multicolumn{2}{|c|}{$\begin{array}{l}\text { East Midlands Electricity..........Dominion Resources } \\
\text { (U.S.) }\end{array}$} & 1996 & $\$ 2.20$ \\
\hline \multirow{2}{*}{\multicolumn{2}{|c|}{$\begin{array}{l}\text { London Electricity ............... Entergy } \\
\text { Yorkshire Electricity ............. American Electric Power }\end{array}$}} & 1996 & $\$ 2.70$ \\
\hline & & & \\
\hline & \& PS Colorado (U.S.) & 1997 & $\$ 2,40$ \\
\hline Northern Group........ & Calenergy (U.S.) & 1996 & $\$ 1.50$ \\
\hline Eastern Group..................... & $\begin{array}{l}\text { Hanson (UK)/ Pacific } \\
\text { Corp (U.S.) }\end{array}$ & $1995 / 1997$ & $\$ 9.60$ \\
\hline \multicolumn{4}{|c|}{$\begin{array}{l}\text { Sourthern Electric................. } \\
\text { Midlands Electricity............ General Public Utilities }\end{array}$} \\
\hline \multicolumn{4}{|c|}{$\begin{array}{r}\text { Midlands Electricity............. General Public Utilities } \\
\& \text { Cinergy (U.S.) }\end{array}$} \\
\hline Manweb........................... & Scottish Power (UK) & 1995 & $\$ 2.70$ \\
\hline SWEB ................. & $\begin{array}{l}\text { Southern Company } \\
\text { (U.S.) }\end{array}$ & 1995 & $\$ 1.70$ \\
\hline \multicolumn{2}{|c|}{$\begin{array}{l}\text { SEEBOARD ...................... Central and South West } \\
\text { (U.S.) }\end{array}$} & 1995 & $\$ 2.50$ \\
\hline NORWEB $\ldots \ldots \ldots \ldots \ldots \ldots \ldots \ldots$ & North West Walter (UK) & 1995 & $\$ 2.70$ \\
\hline SWALEC .............. & Welsh Water (UK) & 1996 & $\$ 1.30$ \\
\hline
\end{tabular}

Source:European Power, Mc Graw-Hill's Independent Power Report, and the Financial Times, various issues. 
Recent Trends In Global FDI Flows: Implications For The 21st Century

Table 3

U.S. direct investment ${ }^{1}$ abroad in selected countries and territories

(millions of dollars)

\begin{tabular}{|c|c|c|c|c|c|c|}
\hline . & & 1990 & & 1996 & & 1997 \\
\hline ALL COUNTRIES & & $\$ 424,086$ & & $\$ 796,494$ & & $\$ 860,723$ \\
\hline Canada & & 67,033 & & 91,587 & & 99,859 \\
\hline Europe ${ }^{2}$ & & 211,194 & & 399,632 & & 420,934 \\
\hline Austria & 889 & & 2,902 & & 2,621 & \\
\hline Belgium & & 9,050 & & 18,604 & & 17,403 \\
\hline Denmark & & 1,597 & 2,171 & 2,576 & & \\
\hline Finland & 551 & 1,033 & 1,338 & & & \\
\hline France & & 18,874 & 34,000 & 34,615 & & \\
\hline Germany & & 27,259 & 44,259 & 43,931 & & \\
\hline Greece & & 288 & 506 & 638 & & \\
\hline Ireland & & 6,880 & 11,749 & 14,476 & & \\
\hline Italy & & 13,117 & & 18,687 & & 17,749 \\
\hline Luxembourg & 1,390 & & 6,377 & & 9,796 & \\
\hline Netherlands & 22,658 & & 44,667 & & 64,648 & \\
\hline Norway & 3,815 & & 6,103 & & 6.262 & \\
\hline Porlugal & 598 & & 1,854 & & 1,498 & \\
\hline Spain & 7,704 & & 11,393 & & 11,642 & \\
\hline Sweden & 1,600 & & 7,629 & & 7,299 & \\
\hline Switzerland & 25,199 & & 35,751 & & 35,203 & \\
\hline Turkey & 494 & & 1,025 & & 1,076 & \\
\hline United Kingdom & 68,224 & & 142,560 & & 138,765 & \\
\hline Eastern Europe & NA & & 6,480 & & 7,743 & \\
\hline South America ${ }^{2}$ & 23,760 & & 52,153 & & 67,112 & \\
\hline Argentina & 2,956 & & 8,060 & & 9,766 & \\
\hline Brazil & 14,918 & & 26,166 & & 35,727 & \\
\hline Chile & 1,368 & & 6,745 & & 7,767 & \\
\hline Colombia & 1,728 & & 3,468 & & 3,727 & \\
\hline Ecuador & 387 & & 855 & & 1,175 & \\
\hline Peru & 410 & & 2,075 & & 2,595 & \\
\hline Venezuela & 1,490 & & 3,592 & & 5,176 & \\
\hline \multicolumn{2}{|l|}{ Central America ${ }^{2}$} & 17,719 & 38,905 & & 48,881 & \\
\hline
\end{tabular}

62 
Recent Trends In Global FD' TFlows: Implications For T'the 21st Century

\begin{tabular}{|c|c|c|c|c|c|c|}
\hline Costa Rica & NA & & 1,205 & & 1,580 & \\
\hline Guatemala & NA & & 217 & & 357 & \\
\hline Honduras & NA & & 145 & & 183 & \\
\hline Mexico & & 9,398 & & 18,747 & & 25,395 \\
\hline Panama & & 7,409 & & 18,256 & & 20,958 \\
\hline Other Western & & & & & & \\
\hline Hemisphere $^{2}$ & & 30,113 & & 53,151 & & 56,489 \\
\hline Bahamas & & 3,309 & & 2,021 & & 1,515 \\
\hline Barbados & NA & & 865 & & 801 & \\
\hline Bermuda & & 21,737 & & 33,783 & & 33,092 \\
\hline Dominican Republic & NA & & 465 & & 476 & \\
\hline Jamaica & 604 & & 1,675 & & 1,687 & \\
\hline $\begin{array}{l}\text { Netherlands } \\
\text { Antilles }\end{array}$ & $-2,229$ & & 3,594 & & 5,393 & \\
\hline Trinidad and Tobago & 508 & & 1,057 & & 602 & \\
\hline $\begin{array}{l}\text { UK islands, } \\
\text { Caribbean }\end{array}$ & 4,800 & & 9,008 & & 12,143 & \\
\hline Africa $^{2}$ & & 4,861 & & 7,568 & & 10,253 \\
\hline Egypt & & 1,465 & & 1,647 & & 1,570 \\
\hline Nigeria & & 161 & & 978 & & 1,465 \\
\hline South Africa & & 956 & & 1,437 & & 2,347 \\
\hline Middle East $^{2}$ & 3,973 & & 8,743 & & 8,959 & \\
\hline Israel & 756 & & 1,886 & & 2,286 & \\
\hline Saudi Arabia & 1,981 & & 3,098 & & 3,079 & \\
\hline United Arab Emirates & s 519 & & 789 & & 682 & \\
\hline Asia and Pacific ${ }^{2}$ & & 61,869 & & 140,402 & & 142,704 \\
\hline Australia & & 14,846 & & 28,769 & & 26,125 \\
\hline China & & NA & & 2,883 & & 5,013 \\
\hline Hong Kong & & 6,187 & & 16,022 & & 19,065 \\
\hline India & & 513 & & 1,139 & & 1,684 \\
\hline
\end{tabular}


Recent Trends In Global FD' Flows: Implications For The 21st Century

\begin{tabular}{|c|c|c|c|c|c|c|}
\hline Indonesia & & 3.226 & & 7.571 & & 7,395 \\
\hline Japan & 20,997 & & 39,593 & & 35,569 & \\
\hline Malaysia & & 1,384 & 5,277 & & 5,623 & \\
\hline New Zealand & & 3,131 & & 5,519 & & 5,191 \\
\hline Philippines & & 1,629 & & 3,349 & & 3,403 \\
\hline Singapore & & 3,385 & & 14,150 & & 17,514 \\
\hline South Korea & & 2,178 & & 5,510 & & 6,528 \\
\hline Taiwan & & 2,014 & & 4,509 & & 4,944 \\
\hline Thailand & & 1,585 & & 5,254 & & 3,537 \\
\hline
\end{tabular}

(1) The book value of U.S. direct investors' equity in, and net outstanding loans to, their foreign affiliates. A foreign affiliate is a foreign business enterprise in which a single U.S. investor owns at least $10 \%$ of the voting securities or the equivalent. (2) Total includes countries not shown. NA $=$ not available.

Source: Bureau of Economic Analysis, U.S. Dept. of Commerce

Table 4

Net Long-term flows to developing countries, 1990-1999 (billions of U.S. dollars)

\begin{tabular}{|l|r|r|r|r|r|r|r|r|r|r|}
\hline & 1990 & 1991 & 1992 & 1993 & 1994 & 1995 & 1996 & 1997 & 1998 & 1999 \\
\hline Total & 98.5 & 124 & 153.7 & 219.2 & 220.4 & 257.2 & 313.1 & 343.7 & 318.3 & 290.7 \\
\hline & 1990 & 1991 & 1992 & 1993 & 1994 & 1995 & 1996 & 1997 & 1998 & 1999 \\
\hline Official Flows & 55.9 & 62.3 & 54 & 53.4 & 45.9 & 53.9 & 31 & 39.9 & 50.6 & 52 \\
\hline & 1990 & 1991 & 1992 & 1993 & 1994 & 1995 & 1996 & 1997 & 1998 & 1999 \\
\hline Private Flows & 42.6 & 61.6 & 99.7 & 165.8 & 174.5 & 203.3 & 282.1 & 303.9 & 267.7 & 238.7 \\
\hline & 1990 & 1991 & 1992 & 1993 & 1994 & 1995 & 1996 & 1997 & 1998 & 1999 \\
\hline $\begin{array}{l}\text { International } \\
\text { Capital } \\
\text { Markets }\end{array}$ & 18.5 & 26.4 & 52.2 & 99.8 & 85.7 & 98.3 & 151.3 & 133.6 & 96.8 & 46.7 \\
\hline & 1990 & 1991 & 1992 & 1993 & 1994 & 1995 & 1996 & 1997 & 1998 & 1999 \\
\hline & 15.7 & 18.8 & 38.1 & 48.8 & 50.5 & 62.2 & 102.1 & 103.4 & 81.2 & 19.1 \\
\hline
\end{tabular}


Recent Trends In Global FDI Flows: Implications For T'he 21st Century

\begin{tabular}{|l|r|r|r|r|r|r|r|r|r|r|}
\hline & 1990 & 1991 & 1992 & 1993 & 1994 & 1995 & 1996 & 1997 & 1998 & 1999 \\
\hline Bank Lending & 3.2 & 5 & 116.4 & 3.5 & 8.8 & 30.4 & 37.5 & 51.6 & 44.6 & 11.4 \\
\hline & 1990 & 1991 & 1992 & 1993 & 1994 & 1995 & 1996 & 1997 & 1998 & 1999 \\
\hline $\begin{array}{l}\text { Bond } \\
\text { Financing }\end{array}$ & 1.2 & 10.9 & 11.1 & 36.6 & 38.2 & 30.8 & 62.4 & 48.9 & 39.7 & 25 \\
\hline & 1990 & 1991 & 1992 & 1993 & 1994 & 1995 & 1996 & 1997 & 1998 & 1999 \\
\hline Other & 11.3 & 2.8 & 10.7 & 8.7 & 3.5 & 1 & 2.2 & 3 & -3.1 & 5.5 \\
\hline & 1990 & 1991 & 1992 & 1993 & 1994 & 1995 & 1996 & 1997 & 1998 & 1999 \\
\hline Equity Flows & 2.8 & 7.6 & 14.1 & 51 & 35.2 & 36.1 & 49.2 & 30.2 & 15.6 & 27.6 \\
\hline & 1990 & 1991 & 1992 & 1993 & 1994 & 1995 & 1996 & 1997 & 1998 & 1999 \\
\hline $\begin{array}{l}\text { Foreign } \\
\text { Direct } \\
\text { Investment }\end{array}$ & 24.1 & 35.1 & 47.5 & 66 & 88.8 & 105 & 130.8 & 170.3 & 170.9 & 192 \\
\hline
\end{tabular}

Note: Net long-term resource flows are defined as net liability transactions of original maturity of greater than one year. Although the Republic of Korea is a high income country it is included in the developing country aggregate since it is a borrower from the World bank.

Source: World Bank Debtor Reporting Systems.

\section{References}

Abugre, C. (n.d). The proposed multilateral investment agreement (MIA) and Africa's desire for foreign direct investment, third world network. http://www.aide.org.za/archives/mia and fdi.html.

Allaoua A., \& Atkin, M. (2000). Foreign direct investment in Africa: Trends, constraints and challenges. Ad-hoc expert meeting on the revitalization of investments for Africa's development: Prospects in the 1990's and Beyond, Economic Commission for Africa, http://www.ifc.org/abn/ library/press0008.htlm.

Albuquerqu, R. (2000). The composition of international capital flows: Risk sharing through foreign direct investment. Bradley Policy Research Center Working Paper No. FR 00-08 (Rochester, New York: University of Rochester). 
Borensztein, E., De Gregorio, J., \& Lee, J.W. (1998). How does foreign direct investment affect growth? Journal of International Economics, $45,115-35$.

Bosworth, B., \& Collins, S. M. (1999). Capital flows to developing economies: Implications for saving and investment. Brookings Papers on Economic Activity: 1, Brookings Institution, 143-69.

Camdessus, M. (2000). Africa can harness globalization. Business Day (South Africa), January 13, 2000.

Global Development Finance (1997). CD-ROM.

Hausmann, R., \& Eduardo, F. A. (2000). Foreign direct investment: Good cholesterol? Inter-American Development Bank Working Paper No. 417 (Washington).

Hill, C. W.L. (1999). International business, competing in the global market place. Boston. Massachusetts: Irwin McGraw-Hill.

International trade indicators network (1998). CD-ROM.

Kregell, J.A. (1996). Some risks and implications of financial globalization for national policy autonomy. UNCTAD Review, 1996.

Lensink, R., \& Morrissey, O. (2000). Aid instability as a measure of uncertainty and the positive impact of Aid on growth. Journal of Development Studies, 36, 3. 31-49.

Lensink R., \& Morrissey, O. (2001). Foreign direct investment: Flows, volatility and growth in developing countries. Credit Research Paper, Centre for Research in Economic Development and International Trade, University of Nottingham, UK.

Lipsey, R. E. (1997). The role of foreign direct investment in international capital flows. National Bureau of Economic Research. nber.org.com.

Loungani, P., \& Assaf, R. (2001 June). How beneficial is foreign direct investment for developing countries. Finance \& Development, 38 (2), A Quarter magazine of the IMF. 
Madura, J. (2000). International financial management. International (ed.). South-Western College Publishing.

Markusen, J R. (1995). The boundaries of multinational enterprises and the theory of international trade. Journal of Economic Perspectives, 9, 169 . 189.

Miyake, M., \& Thomson, S. (1999). Recent trends in foreign direct investment. Financial Market Trends, 73s.

Ndu, C. C., \& Chris, E. (2001). Recent trends in FDI and strategies for attracting more FDI to Africa in the $21^{\text {st }}$ Century. International Academy of African Business and Development.

New Africa.com (2000). Foreign direct investment in Africa: FDI inflows. $\leq$ http://www.newafrica.com/investment/indicators/fdiinflows $>1$.htm.

Saggi, K. (2000). Trade, foreign direct investment, and international technology transfer. World Bank Research Working papers 2349, World Bank.

Shapiro, A. (1999). Multinational financial management. New Jersey: Prentice Hall.

Singh, H., \& Jun, K. W. (1995). Some new evidence on determinants of foreign direct investment in developing countries. NEP series, http:/ ideas.uquam.ca/ideas/data/papers/wopwobaie 1531.

Simon, \& Schuster (2000). The role of foreign direct investment (FDI) in development and growth in OIC member countries. Journal of Economic Cooperation, 21 (3) 2000, 27-55.

United Nations (1999). World Development Report.

United Nations (1998). World Investment Report. New York and Geneva: United Nations 1998.

Wayne, L. (1998). Mergers prepare U.S. companies to take on the world. New York Times, $\left(23^{\text {rd }}\right)$ January.

World Trade Organization (1998). Annual Report. 